\title{
First report of leaf spot of lentil caused by Alternaria tenuissima in India
}

\author{
LAKSHMAN PRASAD ${ }^{*}$, H.K. DIKSHIT ${ }^{2}$, MURALEEDHAR S. ASKI ${ }^{2}$ and T. PRAMEELA DEVI ${ }^{1}$ \\ ${ }^{1}$ Division of Plant Pathology, ${ }^{2}$ Division of Genetics, ICAR-Indian Agricultural Research Institute, New Delhi 110012 , India
}

Received: 18 July 2017/ Accepted: 19 August 2017/ Published online: 31 August 2017

(C) Indian Phytopathological Society 2017

Lentil (Lens culinaris) is an important pulse crop plant belonging to the family Fabaceae. Lentil leaves exhibiting pale to tan spots were observed in the breeding trial fields at Indian Agricultural Research Institute (IARI), New Delhi in February, 2015 (Fig. 1). Brownish spots on leaves later coalescing to form larger patches and consequently caused blighting of the entire leaves and subsequently on pods in circular to crescent shape of tan to dark brown spots later turn to blight.

The causal organism was isolated on PDA medium. The colonies were white, which turned grey to greyish black. Conidiophores were straight or flexuous, subcylindrical, septate, pale or pale brown. Conidia solitary or in short chains; straight or curved, obclavate or with the body of conidium ellipsoidal tapering gradually to the beak which is upto half the length of conidium, sometimes verruculose, and the body 25-63 $\mu \mathrm{m}$ long, 11-14 $\mu \mathrm{m}$ wide, 4-7 transverse and many oblique septa beak pale (Fig. 2) (Ellis, 1971). Based on morphology, the fungus was identified as Alternaria tenuissima (Kunze ex Pers.) Wiltshire (Ellis, 1971; Kumar et al., 2001). Molecular identification of internal transcribed spacer (ITS) region of rDNA of fungus was done using primers ITS1 and ITS4 (White et al., 1990). The amplified PCR product were purified and sequenced. These sequences have $100 \%$ similarities with GenBank (Acc No. KF 494003) sequences of $A$. tenuissima and submitted in NCBI
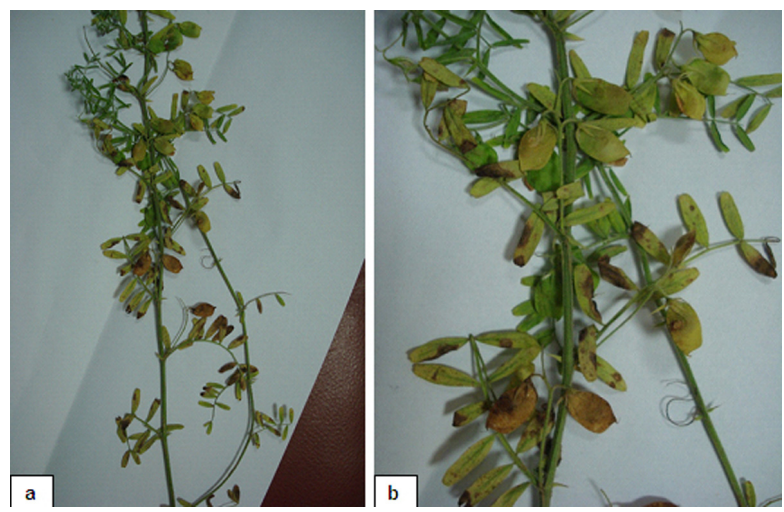

Fig. 1. Alternaria spots on leaves and pods of lentil

*Corresponding author: laxmanprasad25@yahoo.com

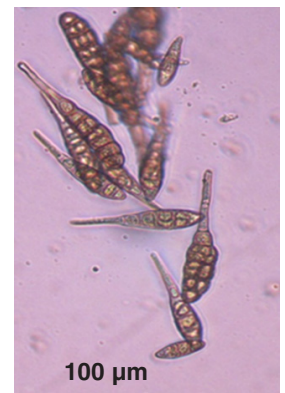

Fig. 2. Conidia of Alternaria tenuissima from lentil

(KX440627). The culture of $A$. tenuissima have been deposited in Indian Type Culture Collection (ITCC No. 8178), Division of Plant Pathology, ICAR-IARI, New Delhi, India.

For pathogenicity tests, 30 days old five healthy plants of $L$. culinaris were sprayed with spore $\left(5 \times 10^{5}\right.$ spore $/ \mathrm{ml}$ ) of the pathogen prepared in sterile water. Five plants were sprayed with sterilized water as negative control. Both sets of plants were kept under controlled humid conditions for six days. Leaves of experimental plant exhibited symptoms identical to field grown plants (Fig. 1b). The pathogen was morphologically identified as $A$. tenussima on re-isolation. This is the first report of leaf spot caused by $A$. tenuissima on lentil in India.

\section{ACKNOWLEDGEMENT}

Authors are thankful to the Director, ICAR-IARI, New Delhi for providing support to carried out this work.

\section{REFERENCES}

Ellis MB (1971). Dematiaceous hyphomycetes. CMI, Kew, Surrey, England pp. 477.

Kumar V, Pandey KN and Joshi GC (2001). Three new host records for Alternaria tenuissima. Indian Phytopath. 54: 400.

White TJ, Brun T, Lee S and Taylor J (1990) Amplification and direct sequencing of fungal ribosomal genes for phylogenetics. In: PCR Protocol: A Guide to Methods and Applications (Eds. Innis MA, Gelfand DH, Sninsky JJ and White TJ, Academic press, New York, U.S.A. pp. 315-322. 